\title{
Factors Affecting the Use of Visual Inspection Acetic Acid Test: Multilevel Analysis on the Contextual Effect of Health Center
}

\author{
Siti Kholifah'), Uki Retno Budihastuti²), Bhisma Murti1) \\ 1)Masters Program in Public Heath, Universitas Sebelas Maret \\ ${ }^{2)}$ Department of Obstetrics and Gynecology, Dr. Moewardi Hospital
}

\begin{abstract}
Background: Cervical cancer is one of the deadliest diseases that are a major cause of female morbidity and mortality in developing countries. This study aimed to determine the effect of health centers on the use of visual inspection acetic acid (VIA) tests using social cognitive theory.

Subjects and Method: This was an analytic observational study with a cross sectional design, conducted at 25 community health centers (Puskesmas) in Surakarta and Karanganyar, Central Java, Indonesia. A sample of 225 married women at reproductive age was selected by random sampling. The dependent variable was the use of VIA test. The independent variables at level 1 were intention, self-efficacy, attitude, outcome expectation, imitation, type of contraceptive method, distance to health service, belief, and time to attend health services. Puskesmas was independent variable at level 2 . The data were collected by questionnaire and analyzed by a multilevel logistic regression.
\end{abstract}

Results: The use of VIA tests was positively affected by intention $(b=1.25 ; 95 \% \mathrm{CI}=0.30$ to -2.13 ; $\mathrm{p}=0.010)$, attitude $(\mathrm{b}=1.25 ; 95 \% \mathrm{CI}=0.30$ to $-2.13 ; \mathrm{p}=0.010)$, outcome expectation $(\mathrm{b}=0.86$; $95 \% \mathrm{CI}=-0.89$ to $-0.19 ; \mathrm{p}=0.076)$, imitation $(\mathrm{b}=1.58 ; 95 \% \mathrm{CI}=0.62$ to $2.54 ; \mathrm{p}=0.001)$, intra uterine device $(\mathrm{b}=1.55 ; 95 \% \mathrm{CI}=0.65$ to $2.45 ; \mathrm{p}=0.001)$, distance $(\mathrm{b}=1.39 ; 95 \% \mathrm{CI}=0.44$ to $2.34 ; \mathrm{p}=$ 0.004), self-efficacy $(b=1.11 ; 95 \% \mathrm{CI}=0.26$ to $1.97 ; \mathrm{p}=0.011)$, trust in health service $(\mathrm{b}=1.84 ; 95 \%$ $\mathrm{CI}=0.87$ to $2.81 ; \mathrm{p}<0.001)$, and spare time to attend health center $(\mathrm{b}=0.76 ; 95 \% \mathrm{CI}=-0.11$ to 1.64; $\mathrm{p}=0.090$ ). Puskesmas accreditation status had contextual effect on the use of VIA tests with $\mathrm{ICC}=30.68 \%$.

Conclusion: The use of VIA tests was positively affected by intention, attitude, outcome expectation, imitation, intrauterine device, distance, self-efficacy, trust in health service, and spare time to attend health center. Puskesmas accreditation status had contextual effect on the use of VIA tests.

Keywords: visual inspection acetic acid, social cognitive theory, multilevel analysis

\section{Correspondence:}

Siti Kholifah. Masters Program in Public Heath, Universitas Sebelas Maret, Jl. Ir. Sutami 36A, Surakarta 57126, Central Java. Email: olifkholifah53@gmail.com. Mobile: 081575644051.

\section{BACKGROUND}

Cervical cancer is ranked second after breast cancer in women worldwide. The cause of cervical cancer is 70\% caused by Human Papilloma Virus (HPV) types 16 and 18. The prevalence of HPV in Central and South America is the highest at a young age of $<25$ years, and increases at an older age of $\leq 45$ years (Burdette et al., 2014; WHO, 2017; Keulen et al., 2017).

More than 20 million new cancer cases were found mainly in low and middle income countries (Ferlay et al., 2015). This is because cervical cancer screening facilities in developing countries are only a few and mostly concentrated in urban areas (Ajenifuja et al., 2013).

VIA test is a very important and simple examination that can be carried out by health personnel who receive training especially doctors, nurses and midwives. VIA test is used at the level of primary health care and secondary to cervical cancer (Emmanuel et al., 2016). 
Journal of Health Promotion and Behavior (2019), 4(1): 1-11

https://doi.org/10.26911/thejhpb.2019.04.01.01

Ministry of Health of the Republic of Indonesia (2017) reported that early detection coverage reached $1,925,943$ people (2.76\%) from 69,739,202 total women of reproductive age in Indonesia. Data from the Central Java Province Health Profile (2017) reported that the coverage of VIA visits was 447,812 (5.07\%) from 8,832-601 women of reproductive age in Central Java. The coverage is still very low, so it requires more effort to reach the target.

The government optimized the early cervical cancer detection program to improve the implementation of prevention and early detection of cancer in women in Indonesia in 2015 to 2019, it is expected that in 2019 the number of women of reproductive age) who make early detection reaches 50 percent (Ministry of Health, 2017).

Public Health Center is a basic health facility that is affordable for all people, especially for the middle to lower economic community. Health centers are expected to become professional health service institutions, which are oriented to service quality that is competent, innovative, needs oriented, and customer or patient satisfaction, especially in accredited Puskesmas (Radito, 2014). Accredited Puskesmas have health personnel who actively provide information and increase women of reproductive age knowledge through counseling, thus motivating women to carry out VIA tests (Lubis et al., 2016).

Based on this, the authors wanted to find out the effect on the individual level and the contextual influence on the public health center on the possible use of VIA tests in Solo and Karanganyar.

\section{SUBJECTS AND METHOD}

\section{Study Design}

This was an analytic observational study with a cross sectional design. The study was conducted in Solo and Karanganyar, Cen- tral Java, Indonesia, from February to March 2019.

\section{Population and Sample}

The target population in this study were women who had taken the VIA test and women who did not take the VIA test. A sample of 225 women aged 20 to 49 years of reproductive age was selected by random sampling.

\section{Study Variables}

The dependent variable was the use of the VIA test. The independent variables at level 1 were intention, self-efficacy, attitude, outcome expectation, imitation, type of contraceptive method, distance, trust in health service, and spare time to attend health service. Puskesmas was an independent variable at level 2.

\section{Operational Definition of Variables}

The use of VIA test was described as the result of the women's answer about the behavior of using the VIA test (ever/never). Selfefficacy was described as the women's ability about self-confidence in driving motivation to routinely conduct VIA tests.

Intention was described as the desire of the women to do or not to do and VIA test. Attitude was described as women's response related to ease or obstacles to influence mothers in conducting VIA tests.

Time was described as the time the women has in addition to the time to work or take care of the household which can be used to conduct an VIA test. The type of family planning is described as a type of contraception used by respondents.

Outcome expectation was described by the results expected by respondents if they take the VIA test and if they do not take the VIA test. Imitation was described as the women actions to imitate other people behavior after seeing other people take VIA tests.

Distance was described as the distance traveled by the respondent to the public 
health centers from the last place of activity. Trust in health service was described by respondents regarding professional services or health personnel to provide VIA test at public health center.

\section{Study Instruments}

The data were collected by a set of questionnaire that has been tested for validity and reliability. The total item value is $>0.2$, Alpha Cronbach >0.7.

\section{Data Analysis}

Univariate analysis was performed to see the frequency distribution and the percentage of the characteristics of the study subjects. Bivariate analysis was conducted to study the relationship between the use of IV test and independent variables using chisquare test and calculation of odds ratio (OR) with a confidence level (CI) of 95\%. Multivariate analysis was performed using logistic regression through a multilevel analysis approach.

\section{Research Ethics}

The research ethics include informed consent, anonymity, confidentiality, and ethical clearance. Ethical clearance was obtained from Research Ethics Committee at Faculty of Medicine, Universitas Sebelas Maret, Surakarta, Central Java, with Number of Ethical Eligibility: 456 / UN27.06 / KEPK / 2019.

\section{RESULTS}

\section{Characteristics Samples}

Table 1 showed a description of the sample characteristics. The majority are 30 years old with a minimum age of 20 years and a maximum age of 40 years. The average value of the intention is 12 with a minimum value of 1 and a maximum value of 24. The average attitude value is 10 with a minimum value of 1 and a maximum value of 20.

The majority of the women's outcome expectation is 10 with a minimum value of 1 and a maximum value of 20. The average value of imitation is 12 with a minimum value of 2 and a maximum value of 24 . The majority of respondents' distance to the Puskesmas is $8 \mathrm{~km}$ with a minimum value of $1 \mathrm{~km}$ and a maximum value of $14 \mathrm{~km}$. The average value of women's self-efficacy was 10.

Table 1. Sample characteristics (continuous data)

\begin{tabular}{lccccc}
\hline Variables & N & Mean & SD & Minimum & Maximum \\
\hline Age (year) & 225 & 30.0 & 5.7 & 20.0 & 40.0 \\
Intention & 225 & 12.0 & 6.2 & 1.0 & 24.0 \\
Attitude & 225 & 10.0 & 5.4 & 1.0 & 20.0 \\
Outcome expectation & 225 & 10.0 & 5.5 & 1.0 & 20.0 \\
Imitation & 225 & 12.0 & 6.6 & 2.0 & 24.0 \\
Distance (km) & 225 & 8.0 & 3.8 & 1.0 & 14.0 \\
Self-Efficacy & 225 & 10.0 & 5.7 & 1.0 & 20.0 \\
\hline
\end{tabular}

\section{Univariate Analysis}

Univariate description of study variables explains the general description of data. Each of the variables studied is described in the table which shows that the percentage of research subjects included: did not do VIA tests totaling 128 (56.89\%). Women with weak intention were $126(56 \%)$ and negative attitude were 133 (59.11\%). Women with positive outcome expectation were 152 people (67.56\%). Women who imitated were 142 (63.11\%). The majority of women used intra uterine device (IUD) contraceptive method with 123 (54.67\%). 
Journal of Health Promotion and Behavior (2019), 4(1): 1-11

https://doi.org/10.26911/thejhpb.2019.04.01.01

Table 2. Sample characteristics (dichotomous data)

\begin{tabular}{llcc}
\hline Characteristics & & $\mathbf{n}$ & \% \\
\hline VIA Test & Yes & 97 & 43.11 \\
Intention & No & 128 & 56.89 \\
& Strong (score $\geq 12)$ & 99 & 44 \\
Attitude & Weak (score $(<12)$ & 126 & 56 \\
& Positive $(\geq 10)$ & 92 & 40.89 \\
Outcome Expectation & Negative $(<10)$ & 133 & 59.11 \\
& Positive $(\geq 10)$ & 152 & 67.56 \\
Imitation & Negative $(<10)$ & 73 & 32.44 \\
Type of family planning & Yes $(\geq 12)$ & 142 & 63.11 \\
& No $(<12)$ & 83 & 36.89 \\
Distance & IUD & 123 & 54.67 \\
& Non IUD & 102 & 45.33 \\
Self-Efficacy & Close $(<8 \mathrm{~km})$ & 150 & 66.67 \\
Trust to health service & Far $(\geq 8 \mathrm{~km})$ & 75 & 33.33 \\
& High $(\geq 10)$ & 102 & 45.33 \\
Time & Low $(<10)$ & 123 & 54.67 \\
& Good & 137 & 60.89 \\
& Poor & 88 & 39.11 \\
& Yes & 97 & 43.11 \\
& No & 128 & 56.89 \\
\hline
\end{tabular}

\section{Bivariate analysis}

Bivariate analysis was used to examine the relationship between independent variables (intention, self-efficacy, attitude, outcome expectation, imitation, type of family planning, distance, trust in health services and time) and the dependent variable (use of VIA test). The results of bivariate analysis can be seen in Table 3 .

Table 3 showed the results of bivariate analysis. $63(63.6 \%)$ of women used the VIA test and had strong intentions (score $\geq 12$ ). Women with strong intention were 5 times more likely to use the VIA test and it was statistically significant $(\mathrm{OR}=$ 4.73; $\mathrm{p}<0.001)$.

Women who used the VIA test had a positive attitude (score $\geq 10$ ) in a total of 53 (57.6\%). Women with positive attitude were 3 times more likely to use the VIA test and it was statistically significant $(\mathrm{OR}=2.74$; $\mathrm{p}<0.001)$.

Women who used the IVA test had a positive outcome expectation (score $\geq 10$ ) which was 83 (54.6\%). Women with a positive outcome expectation were 5 times more likely to use the VIA test and it was statistically significant $(\mathrm{OR}=5.06 ; \mathrm{p}<0.001)$.

A total of 74 (52.1\%) women who used the VIA test performed imitation (score $\geq 12$ ). Women who imitated were 3 times more likely to use the VIA test and it was significant $(\mathrm{OR}=2.83 ; \mathrm{p}<0.001)$.

A total of 76 (61.8\%) women who conducted the VIA test used IUD contraceptive method. Women with IUD were 6 times more likely to use the VIA test and were statistically significant $(\mathrm{OR}=6.23 ; \mathrm{p}$ $<0.001$ ).

Short distance increased the use of VIA test. Distance $(<8 \mathrm{~km})$ increased the likelihood of women to use VIA test and it was statistically significant $(\mathrm{OR}=2.64 ; \mathrm{p}=$ o.001). Strong self-efficacy increased the use of VIA test and it was statistically significant $(\mathrm{OR}=2.43 ; \mathrm{p}=0.001)$.

Trust in health service increased the use of VIA test and it was statistically significant $(\mathrm{OR}=4.36 ; \mathrm{p}<0.001)$. Women who had spare time to attend health service were 2 times more likely to use the VIA test and it was significant $(\mathrm{OR}=1.97 ; \mathrm{p}=0.013)$. 
Kholifah et al./ Factors Affecting the Use of Visual Inspection Acetic Acid Test

Table 3. Bivariate analysis in the use of the IVA test

\begin{tabular}{|c|c|c|c|c|c|c|c|c|}
\hline \multirow{3}{*}{ Variable } & \multicolumn{4}{|c|}{ IVA Test Examination } & \multirow{2}{*}{\multicolumn{2}{|c|}{ Total }} & \multirow{3}{*}{ OR } & \multirow{3}{*}{$\mathbf{p}$} \\
\hline & \multicolumn{2}{|c|}{ No } & \multicolumn{2}{|c|}{ Yes } & & & & \\
\hline & $\mathbf{n}$ & $\%$ & $\mathbf{n}$ & $\%$ & $\mathbf{N}$ & $\%$ & & \\
\hline \multicolumn{9}{|l|}{ Intention } \\
\hline Weak $($ score $<12)$ & 92 & 73 & 34 & 27 & 126 & 100 & \multirow[t]{3}{*}{4.73} & \multirow{3}{*}{$<0.001$} \\
\hline Strong(score $\geq 12$ ) & 36 & 36.4 & 63 & 63.6 & 99 & 100 & & \\
\hline \multicolumn{7}{|l|}{ Attitude } & & \\
\hline Negative $<10$ & 89 & 66.9 & 44 & 33.1 & 133 & 100 & \multirow[t]{2}{*}{2.74} & \multirow{2}{*}{$<0.001$} \\
\hline Positive $\geq 10$ & 39 & 42.4 & 53 & 57.6 & 106 & 100 & & \\
\hline \multicolumn{9}{|l|}{ Outcome Expectation } \\
\hline Negative $<10$ & 59 & 80.8 & 14 & 19.2 & 73 & 100 & \multirow[t]{2}{*}{5.06} & \multirow{3}{*}{$<0.001$} \\
\hline Positive $\geq 10$ & 69 & 45.4 & 83 & 54.6 & 152 & 100 & & \\
\hline \multicolumn{8}{|l|}{ Imitation } & \\
\hline No $<12$ & 60 & 72.3 & 23 & 27.7 & 83 & 100 & \multirow[t]{2}{*}{2.83} & \multirow{2}{*}{$<0.001$} \\
\hline Yes $\geq 12$ & 68 & 47.9 & 74 & 52.1 & 142 & 100 & & \\
\hline \multicolumn{9}{|c|}{ Type of Family Planning } \\
\hline Non IUD & 81 & 79.4 & 21 & 20.06 & 102 & 100 & \multirow[t]{2}{*}{6.23} & \multirow[t]{2}{*}{$<0.001$} \\
\hline IUD & 47 & 38.2 & 76 & 61.8 & 123 & 100 & & \\
\hline $\begin{array}{l}\text { Distance } \\
\text { Far } \geq 8 \mathrm{~km}\end{array}$ & 54 & 72 & 21 & 28 & 75 & 100 & \multirow[t]{3}{*}{2.64} & \multirow[t]{3}{*}{0.001} \\
\hline Close $<8 \mathrm{~km}$ & 74 & 49.3 & 76 & 50.7 & 150 & 100 & & \\
\hline \multicolumn{7}{|l|}{ Self-Efficacy } & & \\
\hline Low $<10$ & 82 & 66.7 & 41 & $33 \cdot 3$ & 123 & 100 & \multirow[t]{3}{*}{2.43} & \multirow[t]{3}{*}{0.001} \\
\hline High $\geq 10$ & 46 & 45.1 & 56 & 54.9 & 102 & 100 & & \\
\hline \multicolumn{7}{|l|}{ Trust to health service } & & \\
\hline Poor & 68 & $77 \cdot 3$ & 20 & 22.7 & 88 & 100 & \multirow[t]{3}{*}{$4 \cdot 36$} & \multirow[t]{2}{*}{$<0.001$} \\
\hline Good & 60 & 43.8 & 77 & 56.2 & 137 & 100 & & \\
\hline Time & & & & & & & & \\
\hline No & 82 & 64.1 & 46 & 35.9 & 128 & 100 & 1.97 & 0.013 \\
\hline Yes & 46 & 47.4 & 51 & 52.6 & 97 & 100 & & \\
\hline
\end{tabular}

\section{Multilevel Analysis}

The number of variables observed was nine at level 1 , one variable at level 2 with the number of observations was 225. The number of groups observed was the health center at level 2, the average group has 9 observation subjects.

Table 4 showed that the use of VIA tests increased with strong intention $(\mathrm{b}=$ $1.23 ; 95 \% \mathrm{CI}=0.32$ to $2.13 ; \mathrm{p}=0.008)$, positive attitude $(b=1.25 ; 95 \% \mathrm{CI}=0.30$ to 2.13; $\mathrm{p}=0.010$ ), positive outcome expectation $(\mathrm{b}=0.86 ; 95 \% \mathrm{CI}=-0.89$ to $-0.19 ; \mathrm{p}=$ 0.076), imitating ( $b=1.58 ; 95 \% \mathrm{CI}=0.62$ to 2.54; $\mathrm{p}=0.001)$, IUD use $(\mathrm{b}=1.55 ; 95 \% \mathrm{CI}=$ 0.65 to $2.45 ; \mathrm{p}=0.001$ ), short distance to health service $(b=1.39 ; 95 \% \mathrm{CI}=0.44$ to
2.34; $\mathrm{p}=0.004)$, high self-efficacy $(b=1.11$; $95 \% \mathrm{CI}=0.26$ to $1.97 ; \mathrm{p}=0.011)$, trust in health service $(b=1.84 ; 95 \% \mathrm{CI}=0.87$ to 2.81 ; $\mathrm{p}<0.001)$, had spare time to attend health service $(b=0.76 ; 95 \% \mathrm{CI}=-0.11$ to $1.64 ; \mathrm{p}=$ o.090).

The result of $\mathrm{ICC}=30.68 \%$ indicated that $30.68 \%$ of the variation in VIA test use was determined by accreditation of health center. This number was greater than the standard size of $8-10 \%$ role of thumb. It was indicated that community health center (Puskesmas) had contextual effect on the use of VIA test. The value of $p=0.001$ indicated that multilevel analysis models had statistically significant differences with the regular logistic regression model. 
Journal of Health Promotion and Behavior (2019), 4(1): 1-11

https://doi.org/10.26911/thejhpb.2019.04.01.01

Table 4. Multilevel logistical analysis

\begin{tabular}{|c|c|c|c|c|}
\hline \multirow{2}{*}{ Independent variables } & \multirow{2}{*}{ b } & \multicolumn{2}{|c|}{$95 \% \mathrm{CI}$} & \multirow[b]{2}{*}{$\mathbf{p}$} \\
\hline & & Lower limit & Upper limit & \\
\hline \multicolumn{5}{|l|}{ Fixed Effect } \\
\hline Intention strong) & 1.23 & 0.32 & 2.13 & 0.008 \\
\hline Attitude (positive) & 1.25 & 0.30 & 2.19 & 0.010 \\
\hline Outcome Expectation (positive) & 0.86 & -0.89 & -0.19 & 0.076 \\
\hline Imitation (yes) & 1.58 & 0.62 & 2.54 & 0.001 \\
\hline Type of FP (IUD) & 1.55 & 0.65 & 2.45 & 0.001 \\
\hline Distance to Health Center (close) & 1.39 & 0.44 & 2.34 & 0.004 \\
\hline Self-efficacy (high) & 1.11 & 0.26 & 1.97 & 0.011 \\
\hline Free time (yes) & 0.76 & -0.11 & 1.64 & 0.090 \\
\hline Trust in health services (high) & 1.84 & 0.87 & 2.81 & $<0.001$ \\
\hline Constants & -7.03 & -9.15 & -4.98 & \\
\hline \multicolumn{5}{|l|}{ Random Effect } \\
\hline \multicolumn{5}{|l|}{ Health center } \\
\hline Variant (constant) & 1.45 & 0.42 & 4.98 & \\
\hline n observation $=225$ & & & & \\
\hline $\mathrm{n}$ health center group $=25$ & & & & \\
\hline Log likelihood $=-87.02$ & & & & \\
\hline LR test vs. Logistic regression, $p=0.001$ & & & & \\
\hline ICC $=30.68 \%$ & & & & \\
\hline
\end{tabular}

\section{DISCUSSION}

\section{The Effect of Intention on the Use of VIA Test}

The results of this study supported the Planned Behavior Theory (TPB) proposed by Ajzen that "the greater the intention, the greater the likelihood of behavior occurrence". Intention was formed from the presence of attitudes toward the behavior of someone (Azwar, 2013; Murti, 2018).

The results of this study were in line with Saptowati et al. (2018), which stated that the use of VIA test was directly affected by intention. Ulfiana (2013) also stated that most women of reproductive age intended to do Pap smear, so that they were able to take a positive attitude to conduct Pap smear to prevent cervical cancer.

\section{The Effect of Attitude on the Use of VIA Test}

The results of this study supported the TPB theory found by Ajzen that attitude was a tendency to respond in the form of beliefs, feelings or behaviors to an idea, object, person and event or social situation that was important which in this case was doing VIA tests. Attitude was influenced by beliefs about behavior (Murti, 2018). Attitude referred to the extent to which a positive or negative evaluation of a person toward the desired behavior (Abiodun et al., 2014).

The results of this study were in line with a study by Fauza et al. (2018), which reported that there was a significant relationship between attitude and participation of women in early detection of cervical cancer with VIA test. Women of reproductive age with positive attitude would influence the desire to do VIA test.

Ranabhat et al. (2014) reported that positive attitude has a direct and significant effect on the use of VIA tests.

\section{The Effect of Outcome Expectation on the Use of VIA Test}

The results of this study were in accordance with Bandura's theory which states that positive out-come expectation would increase behavior and vice versa. Outcome expectation was strongly influenced by the environment in which observers grow (Murti, 2018). MacLaughlin et al. (2011) showed that women who performed cervical cancer 
screening have a positive outcome expectation that can avoid cervical cancer.

\section{The Effect of Imitation on the Use of VIA Test}

The results of this study were in accordance with Social Cognitive Theory (SCT) found by Bandura, stating that when individuals observed a model that was carrying out a behavior, they would use that information to guide the behavior that would be carried out. The process of imitation of someone on the development of someone's personality has a big impact, by following a good example it would encourage individuals to carry out good behavior and vice versa (Murti , 2018).

This study was supported by Sahr et al. (2018), which stated that imitating peers influenced behavior for conducting VIA tests and it was statistically significant.

\section{The Effect of Contraceptive Method on the Use of VIA Test}

Some studies showed that women who have used an intrauterine device (IUD) have a lower risk of cervical cancer (American Cancer, 2016).

The results of this study were supported by Leno et al. (2018), which stated that the majority of women with IUD contraception tend to conduct cervical cancer screening compared to women who use other methods.

Khalili et al. (2015) reported that the majority of women who did cervical cancer screening use IUD contraception. This was because before using IUD contraception, cervical cancer screening wsa done so that women get used to do cervical cancer screening.

\section{The Effect of Distance on the Use of VIA Test}

The results of this study supported the PRECEDE-PROCEED theory that distance was one of the enabling factors. The distance to access health services that were too far away and the difficulty of getting public transportation were some of the factors that have prevented women of reproductive age from conducting VIA tests.

Alfaro et al. (2015) showed that women of reproductive age which had an access distance of $<10 \mathrm{~km}$ to a health care facility, tended to do an VIA test compared to a distance of $>10 \mathrm{~km}$. Nordianti et al. (2018) stated that the affordability of distance affected women to do VIA tests to the health center significantly.

\section{The Effect of Self-Efficacy on the Use of VIA Test}

The results of this study were in accordance with social cognitive theory, one of the constructs was self-efficacy. The more skilled an individual was in carrying out a behavior, the greater the individual's self-confidence in carrying out the behavior (Murti, 2018).

The results of the study by Sidabutar et al. (2017) showed that there was a significant relationship between self-efficacy and the use of VIA tests. Self-efficacy increased women awareness and confidence in conducting VIA tests. Higgins et al. (2016) reported that women with positive self-efficacy had a significant influence on the use of pap smears.

\section{The Effect of Health Service Trust on the Use of VIA Test}

The results of this study were in accordance with the PRECEDE-PROCEED theory that trust in health services was one of the enabling factors. Health personnel in providing services have a huge influence on the use of VIA tests, because they were considered as sources of information and experts in the health field (Chang et al., 2017).

The results of study by Lubis et al. (2016), which stated that support from health care providers had a significant relationship with mothers from participation of couples of reproductive age for the VIA test. 
According to the results of a study by Sundari et al. (2018), it was found that mothers who received good support from health personnel mostly conducted VIA test.

\section{The Effect of Time on the Use of VIA Test}

The results of this study were in accordance with the PRECEDE-PROCEED theory that time was one of the enabling factors. Free time was the time available for conducting VIA test. Working women have the opportunity to get information about VIA test examinations from coworkers. But they would tend to spend more time at work so they did not have time to conduct VIA test (Wulandari, 2018). The results of a study by Wongwatcharanukul et al. (2014) showed that the majority of women who were busy did not get cervical cancer screening.

\section{The Effect of Health Center Level on the Use of VIA Test}

The quality of cervical cancer prevention service providers was a major determinant of women in doing cervical cancer screening in developing countries. Service providers include health personnel, leadership/ governance, finance, and information (Nwobodo et al., 2016).

Health center was a basic health facility that was affordable for all people, especially for the middle to lower economic community. The health center was expected to become a professional health service institution, which was oriented to service quality that was competent, innovative, needs oriented, and customer or patient satisfaction, especially in accredited health center (Radito, 2014). Accredited health centers have health personnel who actively provide information and increase women's knowledge through counseling so as to motivate WRA to carry out VIA tests (Lubis et al., 2016).

\section{AUTHOR CONTRIBUTION}

$\overline{\text { Siti Kholifah collected the data, analyzed }}$ the data, and wrote the paper. Uki Retno Budihastuti suggested in the discussion. Bhisma Murti arranged the conceptual framework, ran the data analysis, and interpreted the results of data analysis.

\section{FUNDING AND SPONSORSHIP}

This study used the authors' independent funds.

\section{CONFLICT OF INTEREST}

There is no conflict of interest in this study.

\section{ACKNOWLEDGEMENT}

Authors would like to thank to the 25 heads of health center in Surakarta and Karanganyar, Central Java, who gave permission to collect the data. Thank to the enumerators and midwives who helped in the data collection for this study.

\section{REFERENCE}

Abiodun OA, Abiodun O, Sotunsa O, Oluwole F (2014). Impact of health education intervention on knowledge and perception of cervical cancer and cervical screening uptake among adult women in rural communities in Nigeria. BMC Public Health. 14(814): 14712458. http://dx.doi.org/10.1186/14712458-14-814\%5.

Ajenifuja KO, Gage JC, Adepiti AC, Wentzensen N, Eklund C, Reilly M, Schiffman M (2013). Acetic Acid ( VIA ) for Cervical Screening in Rural Nigeria. International Journal of Gynaecological Cancers. 23(3): 507-512. https://doi.org/10.1097/IGC.obo13e31828of 395 .

Alfaro KM, Gage JC, Rosenbaum, AJ, Ditzian LR, Maza M, Scarinci IC, Cremer ML (2015). Factors affecting attendance to cervical cancer screening a- 
mong women in the Paracentral Region of El Salvador: A nested study within the CAPE HPV screening program Chronic Disease epidemiology. BMC Public Health. 15(1): 1-8. https://doi.org/10.1186/s12889-015-2360-7.

American Cancer (2016). About cervical cancer.

Azwar (2013). Sikap manusia teori dan pengukurannya. Edisi 2. Yogyakarta: Pustaka Pelajar.

Burdette AM, Gordon JH, Hill TD (2014). Social determinants of HPV vaccination delay rationales: Evidence from the 2011 National Immunization Survey-Teen. Preventive Medicine Reports. 1(2014): 21-26. https://doi.org/10.1016/j.pmedr.2014.09.003.

Chang HK, Myong JP, Byun SW, Lee SJ, Lee YS, Lee HN, Park TC (2017). Factors associated with participation in cervical cancer screening among young Koreans: A nationwide crosssectional study. BMJ Open. 7(4): 1-3. https://doi.org/10.1136/bmjopen2016-013868.

Fauza M, Aprianti, Azrimaidaliza (2018). Faktor yang berhubungan dengan deteksi dini kanker serviks. Jurnal Promosi Kesehatan Indonesia. 14(1): 68. https://doi.org/10.14710/jpki.14.1.

Ferlay J, Soerjomataram I, Dikshit R, Eser, S, Mathers C, Rebelo M, Bray F (2015). Cancer incidence and mortality worldwide: Sources, methods and major patterns in GLOBOCAN 2012, 386. https://doi.org/10.1002/ijc.29210.

Higgins LM, Dirksing KN, Ding L, Morrow CD, Widdice LA, Kahn JA (2016). Adolescents' intention and self-efficacy to follow Pap testing recommendations after receiving the HPV vaccine. Human Vaccines and Immu- notherapeutics. 12(6): 1498-1503. https://doi.org/10.1080/21645515.2016.1150395.

Keulen HM, Pot M, Ruiter RAC, Eekhout I, Mollema L, Paulussen TWGM (2017). Motivational and contextual determinants of hpv-vaccination uptake: a longitudinal study among mothers of girls invited for the HPV-vaccination. Preventive Medicine. 100(2017): 4149. https://doi.org/10.1016/j.ypmed.2017.04.005.

Khalili FA, Salehi PH, Shahnazi M, Yaghoubi S, Gahremani NP (2015). Cervical cancer screening in women referred to healthcare centres in Tabriz, Iran. Nigerian Medical Journal. 56(1): 28. https://doi.org/10.4103/o300-1652.149167.

Leno DWA, Diallo FD, Delamou A, Komano FD, Magassouba M, Niamy D, Keita N (2018). Integration of Family planning counselling to mass screening campaign for cervical cancer: Experience from Guinea. Obstetrics and Gynecology International. 2018(1): 16. https://doi.org/10.1155/2018/3712948.

Lubis Z, Muda S, Rasmaliah (2016). Analisa hubungan faktor predisposisi pendukung dan penguat dengan keikutsertaan ibu pasangan usia subur untuk tes-IVA di wilayah kerja Puskesmas Helvetia Kecamatan Medan Helvetia Tahun 2016. 169-176. https://doi.org/10.13833/j.cnki.is.2016.10.031.

MacLaughlin KL, Angstman KB, Flynn PM, Schmit JR, Weaver AL, Shuster LT (2011). Predictors of patient comfort and adherence with less frequent cervical cancer screening. Quality in Primary Care. 19(6): 355-363. doi:10.13140/RG.2.1.2605.6800.

Ministry of Health (2017). Profile kesehatan Indonesia 2017. Ministry of He- 
alth Indonesia. https://doi.org/10.1002/qj.

Murti B (2018). Teori Promosi Kesehatan dan Perilaku Kesehatan.

Nordianti ME (2018). Determinan kunjungan inspeksi visual asam asetat di Puskesmas Kota Semarang. Higeia Journal of Public Health Research and Development. 2(1): 33-44. https://journal.unnes.ac.id/sju/index .php/higeia/article/view/19049.

Nwobodo H, Ba-Break M (2016). Analysis of the determinants of low cervical cancer screening uptake among Nigerian women. Journal of Public Health in Africa. 6(2): 12-19. https://doi.org/10.4081/jphia.2015.484.

Emmanuel OG (2016). Reliability of visual inspection after acetic acid staining in screening for cervical pre-malignant lesion among female subjects in a rural tertiary hospital in Nigeria. Cancer Research Journal. 4(1): 1. https://doi.org/10.11648/j.crj.20160401.11.

Radito A (2014). Analisis pengaruh kualitas pelayanan dan fasilitas kesehatan terhadap kepuasan pasien Puskesmas. Ilmu Manajemen. 11(2): 1-26. https://doi.org/10.21831/jim.v11i2.11753.

Ranabhat S, Tiwari M, Dhungana G, Shrestha $\mathrm{R}$ (2014). Association of knowledge, attitude and demographic variables with cervical pap smear practice in Nepal. Asian Pacific Journal of Cancer Prevention. 15(20): 8905-8910. https://doi.org/10.7314/APJCP.2014.15.20.8905.

Sahr LA, Kusumaningrum TAI (2018). Persepsi dan perilaku wanita usia subur dalam melakukan tes inspeksi visual asam asetat. Jurnal Promosi Kesehatan Indonesia. 13(2): 114. https://doi.org/10.14710/jpki.13.2.114128.

Saptowati D, Mudigdo A, Murti B (2018).
Biopsychosocial determinants of Visual Inspection Acetic-acid test uptake in Sragen, Central Java. Journal of Maternal and Child Health. 03(03): 197-206. https://doi.org/10.26911/thejmch.2018.03.03.04.

Sidabutar S, Martini S, Wahyuni CU (2017). Analysis of factors affecting women of childbearing age to screen using Visual Inspection with Acetic Acid. Osong Public Health and Research Perspectives. 8(1): 61-64. https://doi.org/10.24171/j.phrp.2017.8.1.08.

Sundari, Setiawati E (2018). Pengetahuan dan dukungan sosial mempengaruhi perilaku deteksi dini kanker serviks metode IVA. Indonesian Journal of Midwivery. 1(1):6-11.http://jurnal.unw.ac.id/index.php/ijm.

Ulfiana E (2013). Analisis faktor yang mempengaruhi niat wanita pasangan usia subur untuk papsmear di wilayah Kelurahan Kedungmundu Wilayah Puskesmas Kedungmundu Kota Semarang. Jurnal Kebidanan. 2(4): 516o. http://dx.doi.org/10.31983/jkb.v$2 \mathrm{i} 4.100$.

WHO (2017). Prevention of cervical cancer through screening using Visual Inspection with Acetic Acid (VIA) and treatment with cryotherapy. Geneva, Switzerland: the WHO Document Production Services. Retrieved from https://apps.who.int/iris/bitstream/h andle/10665/75250/978924150386o _eng.pdf;jsessionid $=8043364470273$ B3F1CC6702877AA9891? sequence=1.

Wongwatcharanukul L, Promthet S, Bradshaw P, Jirapornkul C, Tungsrithong $N$ (2014). Factors affecting cervical cancer screening uptake by Hmong hilltribe women in Thailand. Asian Pacific Journal of Cancer Prevention: APJCP, 15(8): 3753-3756. https://doi.org/10.7314/APJCP.2014.15.8.37- 
Kholifah et al./ Factors Affecting the Use of Visual Inspection Acetic Acid Test

53.

Wulandari A (2018). Faktor-faktor yang berhubungan dengan perilaku pemeriksaan Inspeksi Visual Asam Asetat (IVA) pada Wanita Usia Subur (WUS) di Puskesmas Sukmajaya Tahun 2016. Jurnal Kesehatan. 2 (1): 93-101. Retrieved from http://juke.kedokteran.unila.ac.id/index.php/JK/article/view/1943. 